\title{
Clinical Presentations and Outcome of Acute Glomerulonephritis in Children
}

\author{
*Akteruzzaman $\mathrm{M}^{1}$, Paul SK ${ }^{2}$, Praveen $S^{3}$, Sarkar $\mathrm{NR}^{4}$, Ahmed $S^{5}$, Habib RB ${ }^{6}$, Kabir ARM L ${ }^{7}$
}

\begin{abstract}
Acute post streptococcal glomerulonephritis (APSGN) is the most common type of acute glomerulonephritis (AGN) in childhood. It has not been studied well in Bangladesh. To evaluate the clinical characteristics, complications and outcome of Acute post streptococcal glomerulonephritis (AGN). the department of Pediatric Nephrology at Sir Salimullah Medical College and Mitford Hospital, Dhaka. A prospective study from April 2011 to March 2012 were conducted among the patients diagnosed as $A G N$ in outdoor and indoor department. Hospital records of all 34 children who had been admitted to Sir Salimullah Medical College and Mitford Hospital were reviewed. All demographic, clinical, paraclinical data and consumed medications were obtained. Among 34 cases female and male ratio were 2.4:1; mean age of was 8.76 yrs. \pm 2.5 SD and peak age 7.6. Etiology of AGN was post infectious glomerulonephritis (PIGN) 85.3\%, ASO titer was raised in $88.2 \%, 41.2 \%$ had raised blood urea, and $32.4 \%$ raised serum creatinine level. All children presented with microscopic hematuria (100\%), hypertension (100\%), and edema (100\%), other findings are fever (55.9\%), oliguria (94.1\%), abdominal pain (52.9\%). History of sore throat and pyoderma was present in $41.2 \%$ and $44.1 \%$ cases respectively.
\end{abstract}

1. *Dr. Mohammad Akteruzzaman Junior Consultant (Pediatrics), Upazila health complex, Kachua, Chandpur. E-mail-akdr_10@yahoo.com

2. Dr. Shanjoy Kumar Paul Prof of Pediatric Nephrology, Sir Salimullah Medical College, Dhaka.

3. Dr. Shaman Parveen, Assistant Registrar, National Institute of Mental Health, Dhaka.

4. Dr. Nihar Ranjan Sarker, Associate professor, Dept of Paediatrics, Shaheed Suhrawardi Medical College Hospital.

5. Dr. Shafi Ahmed, Associate Professor, Northern Medical College, Dhaka.

6. Dr. Rahat Bin Habib, Research assistant, Department of Paediatrics, Sir Salimullah Medical College \& Mitford Hospital, Dhaka, Bangladesh.

7. Dr. ARM Luthful Kabir, Professor of Pediatrics, Ad-din Women's Medical College, Bara Moghbazar, Dhaka.

*For correspondence
Complications like hypertensive encephalopathy three (8.8\%), urinary tract infection (UTI) one (2.9\%) total seven (20\%) were heart failure two (5.9\%) and Acute kidney injury (AKI) one (2.9\%), total seven (20\%) were expired. Majority of cases manifest typically with edema, oliguria and hematuria. It usually has an uneventful course.

Keywords: APSGN; Glomerulonephritis; Hypertension; Edema.

\section{INTRODUCTION}

Acute glomerular disease indicates that the initial and major point of impact is within the renal tissue. ${ }^{1} \mathrm{It}$ comprises a specific set of renal diseases in which an immunologic mechanism triggers inflammation and proliferation of the glomerular tissue that can result in damage to the basement membrane, mesangium or capillary endothelium. ${ }^{2}$

Acute post-streptococcal glomerulonephritis (APSGN) is the most common type of glomerulonephritis (GN) in childhood. ${ }^{3}$ It usually occurs after a recent infection by group A beta-hemolytic streptococcus, and therefore known as post-streptococcal acute glomerulonephritis. ${ }^{4}$ Despite a well-known association between streptococcal infection and APSGN for more than hundred years, the exact cause and also the reason that only certain strains are nephritogenic are not known yet. ${ }^{5-7}$ Nevertheless, the disease has been reported following other bacterial, viral, parasitic, rickettsia, and fungal infections. ${ }^{8}$ Over the past 20 years there has been a substantial decline in the reported incidence of APSGN in many industrialized countries. ${ }^{9-11}$

Acute glomerulonephritis (AGN) is a form of GN characterized by a sudden decline in glomerular filtration rate with clinical manifestations such as edema, hematuria, hypertension, oliguria and renalinsufficiency. ${ }^{12}$ Therefore, AGN is often referred as acute nephritic syndrome (ANS).

It is estimated that 470,000 new annual cases of PSGN are developed worldwide, 97 percent occur in developing countries, with an annual incidence of 9.5 to 28.5 per 100,000 individuals. ${ }^{7}$ In outpatient pediatric department of Bangabandhu Sheikh Mujib Medical University, Dhaka $2.76 \%$ children are diagnosed as APSGN. ${ }^{13}$ 
The overall incidence and patterns of disease in this population have not been characterized and not well documented in Bangladesh. Very few studies have been performed in this regard. An epidemiological study at the national level is not available yet. The risk of PSGN is increased in children between 5 and 12 years of age. It is twice more frequent in male than females. ${ }^{15}$ Clinical presentation may vary from one patient to another patient. The final diagnosis of renal disease, associated with acute renal failure, nephritic syndrome or nephrotic syndrome, is made possible with the study of renal biopsy using light microscopy (LM), immunofluorescence (IF) and electron microscopy (EM). ${ }^{14}$

The present study has been undertaken to evaluate the clinical presentation, complications and outcome. Material \& Methods: children with AGN in Bangladesh.

\section{MATERIAL AND METHODS}

This prospective study was conducted between April 2011 and March 2012 in the department of Pediatric Nephrology at Sir Salimullah Medical College Mitford Hospital, Dhaka. A total of 34 cases aged 3-15 years were included from both outdoor and indoor. Verbal consent was taken from parents or guardians. A data collection sheet was developed and detail history was taken from the parents/guardians/older children. Clinical examination was performed and noted, followed by relevant investigations. Urinalysis on admission, complete blood count with erythrocyte sedimentation rate, C3 level, anti-streptolysin $\mathrm{O}(\mathrm{ASO})$ titer, serum creatinine, serum electrolytes, ultrasound of KUB, and kidney biopsy (if indicated) were done. Statistical analysis was performed using SPSS 20 package.

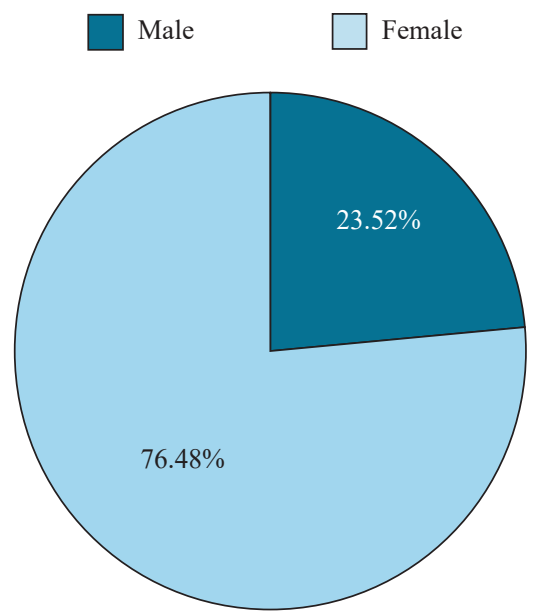

Figure 1: Sex of the study Population

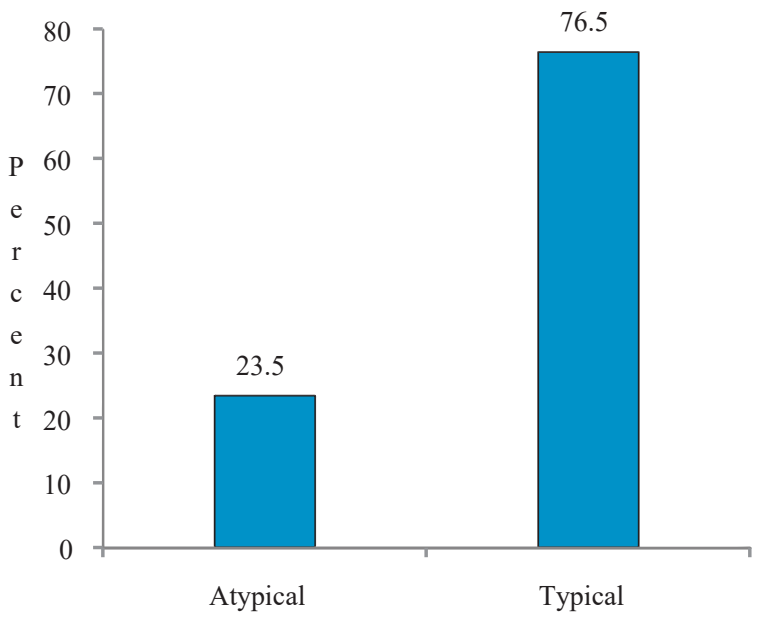

Figure 2: Clinical presentation

\section{RESULTS}

Among thirty four children, boys were 24 and girls 10 with a male female ratio of $2.4: 1$. Their ages ranged from three years to 15 years and $91.2 \%$ were between $6-15$ years. Mean age of presentation was $8.76 \mathrm{yrs} . \pm 2.5 \mathrm{SD}$. Peak age was 7.6.

Fourteen children (41.2\%) had a history of preceding sore throat or upper respiratory infection 7-21days before admission. 15 children (44.1\%) had skin infection (pyoderma) 10-24 days before hospitalization.

Among one hundred and thirty seven children with AGN, $(85.3 \% \%)$ had APSGN. The most frequent clinical findings were edema, gross hematuria and hypertension. Convulsion with very high blood pressure was reported in three children.

Elevated serum creatinine was normalized within two weeks of hospital stay. One children developed rapidly glomerulonephritis (RPGN) for which biopsy was done. He received methyl prednisolone pulses along with peritoneal dialysis.

Seven $(20.54 \%)$ presented with atypical presentation or complications e.g. hypertensive encephalopathy-three (8.8\%), heart failure-two (5.9\%), UTI-one $(2.9 \%)$ and acute kidney injury (AKI)-one (2.9\%).

Regarding medication, $67 \%(\mathrm{n}=23)$ patients received only frusemide, $14.7 \%(\mathrm{n}=5)$ cases frusemide and nifedipine, $2.9 \%(n=1)$ cases furosemide and captopril, $2.9 \%(n=1)$ cases frusemide and amlodipine, $2.9 \%(\mathrm{n}=1)$ cases furosemide, nifedipine and another antihypertensive medication. Anti-hypertensive drug other than diuretics was usedin $32.4 \%$ cases. Antibiotics was used in 15 (44.1\%) cases for active infection. All patients were improved except one $(2.9 \%)$ who developed RPGN and expired due to AKI. 
Table I : Clinical findings of Glomerulonephritis $(n=34)$

\begin{tabular}{|l|c|}
\hline Clinical findings & $\begin{array}{c}\text { No. of Patient } \\
\text { (Percentage) }\end{array}$ \\
\hline Periorbital edema & $34(100 \%)$ \\
\hline Hypertension & $34(100 \%)$ \\
\hline Oliguria & $32(94.1 \%)$ \\
\hline Fever & $19(55.9 \%)$ \\
\hline Gross hematuria & $18(52.9 \%)$ \\
\hline Abdominal pain & $18(52.9 \%)$ \\
\hline Pyoderma & $15(44.1 \%)$ \\
\hline Headache & $14(41.2 \%)$ \\
\hline Vomiting & $14(41.2 \%)$ \\
\hline Sore Throat & $14(41.2 \%)$ \\
\hline Cough & $12(35.3 \%)$ \\
\hline Hepatomegaly & $12(35.3 \%)$ \\
\hline Burning micturition & $10(29.4 \%)$ \\
\hline Shortness of breath & $7(20.6 \%)$ \\
\hline Diarrhea & $4(11.76 \%)$ \\
\hline Altered sensorium & $4(11.76 \%)$ \\
\hline Joint pain & $4(11.76)$ \\
\hline Convulsion & $2(5.9 \%)$ \\
\hline
\end{tabular}

Table II: Paraclinical findings in AGN ( $n=34)$

\begin{tabular}{|l|c|}
\hline Laboratory findings & Frequency \\
\hline Microscopic hematuria & $34(100)$ \\
\hline Pus cell $>5 / \mathrm{HPF}$ & $7(20.6 \%)$ \\
\hline Proteinuria (1+) & $34(100 \%)$ \\
\hline Massive proteinuria $(3+/ 4+)$ & $4(11.6 \%)$ \\
\hline Hemoglobin $(<12 \mathrm{mg} / \mathrm{dl})$ & $19(55.9 \%)$ \\
\hline Raised ESR & $19(55.9 \%)$ \\
\hline Raised blood urea level & $14(41.2 \%)$ \\
\hline Raised serum creatinine & $11(32.4 \%)$ \\
\hline Hyponatremia $(\mathrm{Na}<135 \mathrm{mEq} / \mathrm{L})$ & $2(5.9 \%)$ \\
\hline Hyperkalemia $(\mathrm{K}>5.5 \mathrm{mEq} / \mathrm{L})$ & $3(8.8 \%)$ \\
\hline Raised ASO titre & $30(88.2 \%)$ \\
\hline Low serum C3 Level & $31(91.2 \%)$ \\
\hline High serum cholesterol $(>220 \mathrm{mg} / \mathrm{dl})$ & $3(8.8 \%)$ \\
\hline Hypoalbuminemia & $5(14.7 \%)$ \\
\hline Positive urine culture & $1(2.9)$ \\
\hline Pleural effusion in X-ray chest & $3(8.8 \%)$ \\
\hline
\end{tabular}

\section{DISCUSSION}

The global burden of severe Group A streptococcal disease is concentrated largely in developing countries including Bangladesh. Majority of the cases $(91.5 \%)$ were above 5 years (school going age).In Nepal, mean age of presentation was 9.2 yrs. $\pm 3.1 \mathrm{SD} .{ }^{16}$ The age range in children with APSGN was 3.5 to 13 years with mean of $8.5+$ + 3.2 years. ${ }^{17,18,19,20}$ These results are in accordance with findings of the present studies. In our study, male female ratio was 2.4:1.In other studies, almost equal proportion of female and male were found $(1.08: 1 \& 1.1: 1) .{ }^{16,21}$ Male female ratio was 3.03:1 \& 1.6:1 in some studies. ${ }^{17,22}$ The reasons for this gender variation are not known.

In the present study, antecedent sore throat was observed in $41.2 \% \%$ of cases.It was lower in Nepal, Nigeria and India in $(25.5 \%),(25 \%)$ and $(20 \%)$ respectively. ${ }^{16,24,23}$ Similar result in Indonesia (45.8\%). ${ }^{25}$ but high in United States of America (USA) in (62.1\%). ${ }^{26}$ Pyoderma was observed in $44.1 \%$ of cases this study.Other studies lower in Nigeria and Nepal in (10\%) and (19.1\%) respectively, ${ }^{24,16}$ but higher in India,(60\%). ${ }^{23}$ This was similar in Indonesia and USA in (31.6\%) and (37.9\%) respectively. ${ }^{25}$, ${ }^{26}$ In the present study, antecedent sore throat was observed in $41.2 \% \%$ of cases. Similar result in Indonesia $(45.8 \%){ }^{25}$ Itwas lower in Nepal, Nigeria and India in (25.5\%), (25\%) and $(20 \%)$ respectively. ${ }^{16,24,23}$ but high in United States of America (USA) in (62.1\%). ${ }^{26}$

Edema similar to our studies in India, Nepal and, Iran $(83.4 \%)$ and $(97.5 \%)$ respectively. ${ }^{23,16}, 17$ Lower in Indonesia and Nigeria in $76.3 \%$ and $80 \% .{ }^{25,24}$ Reasons for variation as different grading edema was included in different studies. Gross hematuria was found in $30-70 \%$ of children with AGN which was similar to the present study .16, 23,25,27,28, 29,30, 31

Hypertension was observed in all of our children. Almost similar result was observed by Nepal, Iran, USA, India, Nigeria (86.2\%), (75\%),(73.7\%), (69.1\%) and (55\%) respectively. ${ }^{16} 17,26,23,24$ Oliguria similar in India and Nigeria(90\%), and $(80 \%)$ respectively. ${ }^{23},{ }^{24}$ otherstudies lower in Nepal and Indonesiain (22.2\%) and(23.9\%) respectively. ${ }^{16,25}$

Fever $55.9 \%$ in this study which was similar to Nepal $(63.8 \%)$ but lower Iran (20\%). ${ }^{16},{ }^{17}$ Abdominal pain similar to Iran (20\%) But higher than in Nepal (33.6\%). ${ }^{17}$ ${ }^{22}$ So atypical presentation was more in Nepal.

Among thirty four children AGN, (85.3\%) was APSGN. It is similar (89\%) in Iran. ${ }^{17}$ But lower in Indonesian children $(66.6 \%)$ of cases. $^{25}$ Factors were age, under nutritional status, low socioeconomic status, less of maternal education level and the rainy season. ${ }^{17}$ 
The incidenceof hypertensive encephalopathy observed in our study $(8.8 \%)$ was similar to other studies in Nepal, India and Nigeria (9.57\%),(3.4) \% and (15\%) respectively. ${ }^{16,23,24}$ Azotemia was similar to that observed in Nepal (47.8\%). ${ }^{16}$ It was high in Iran (80\%) and lowin Indonesia (10.5\%). ${ }^{17,25}$

Microscopic hematuria was found in $100 \%$ of the cases in the present study, which is similar to many other studies. In India by Puri $\mathrm{R} \mathrm{K}$ et al, showed that the degree of hematuria does not indicate the severity or prognosis of the disease. ${ }^{27} \mathrm{RBC}$ casts were found to be similar to Indonesia, India $(44.3 \%)$ and $(37.1 \%)$ respectively. ${ }^{25}, 23$ Higher percentage were observed by Travis and Kalian (60-85\%)also found in USA and Nigeria (80\%) and (65\%) respectively. $28,26,24$

The proportion of elevated ESR in our cases was $55.9 \%$ lower than that reported Nepal (95\%), Indonesia (85.3\%) and Iran (70\%). ${ }^{27,25,17}$ Our study in was much higher than India (19.8\%). ${ }^{23}$ Anemiaas indicated by hemoglobin levels $<10 \mathrm{~g} / \mathrm{dl}$ was reported India $(27.1 \%) .{ }^{23}$ In our study it was higher $(55.9 \%)$ which is similar to many other studies in Indonesia (61\%), Iran(51.6\%), Nigeria (50\%) and India (44\%). 25, 17, 24, 27 Reduction in hemoglobin and hematocrit is believed to be due to hemodilution as well as hematuria. Hypoproteinemia is also in part due to the delusionaleffect of intravascular volume expanansion. ${ }^{28,32}$

Pleural effusion in our study was similar to Manhaset al. $(3 \%) .{ }^{23}$ But pleural effusion with other radiological abnormalities were very high in studies done by Kirckpatrick et al (85.5\%) and Puri et al. (72\%), by Albert and Rouf(81.6\%) radiological abnormalities due to pleural effusion and other abnormalities pulmonary edema and pneumonia included. ${ }^{33,27,25}$

Hypertensive encephalopathy was observed in $8.8 \%$ cases in this study which is similar to other study in Nepal, India and Nigeria $9.57 \%, 3.4 \%$ and $15 \%$ respectively. ${ }^{16,23,24} \mathrm{AKI}$ was observed in higher proportion of cases by Ibadin and Abiodun (39.7\%), GI McGIllUgwu (40\%). ${ }^{34,24}$ But our study finding was similar to a study by Shah GS (6.38\%). ${ }^{16}$

\section{CONCLUSIONS}

Although majority of cases manifest typically with edema, oliguria and hematuria, atypical manifestations are not uncommon. Gross alterations of serum electrolytes do not occur in APSGN.

\section{REFERENCES}

1. Madani A, Fahimi D, Esfehani ST et al. Glomerular disease Iranian Children: Clinico -pathological correlations. Pediatrnephrol 2003; 18:925-928.
2. Brouhard BH,Travis LB. Acute post streptococcal glomerulonephritis. In: EdelmanCM (jnr), ed. Pediatric Kidney Disease. Boston: Little, Brown and Co, 1992:1169-1221.

3. Pan CG. Glomerulonephritis in childhood. Curr Opin Pediatr. 1997; 9(2):154-9.

4. Behrman RE, Kliegman R. Acute poststreptococca glomerulonephritis. In: Nelson's essentials of pediatrics. Philadelphia: WB Saunders and company; 1990. 566-7.

5. Batsford SR, Mezzano S, Mihatsch M, et al.Is the nephritogenic antigen in post streptococcal glomerulonephritis pyrogenic exotoxin B (SPE B) or GAPDH? Kidney Int. 2005; 68(3):1120-9.

6. Yoshizawa N, Yamakami K, Fujino $M$, et al. Nephritis-associated plasmin receptor and acute post streptococcalglomerulonephritis: characterization of the antigen and associated immune response. J Am SocNephrol 2004; 15(5):1785-93

7. Rodriguez-Iturbe B, Musser JM. The current state of post streptococcal glomerulonephritis. J Am Soc Nephrol 2008; 19:1855

8. Fleisher DS, Voci G, Garfunkel J, Purungganan H, Kirkpatrick JJ, Wells R, et al. Hemodynamic findings inacute glomerulonephritis. J Pediatr 1966; 69: 1054-62

9. Yap HK, Chia KS , Murugasu B , Saw AH, Tay JS, Ikshuvanam M, Tan KW, Cheng HK, Tan CL, Lim $\mathrm{CH}, 1990$. Acute glomerulonephritis-changing patterns in Singapore children. PediatrNephrol 4: 482 --84.

10. 10.Zhang Y, ShenY, Feld LG, Stapleton FB. Changing patternof glomerular disease at Beijing Children's Hospital. ClinPediatr(Phila) 1994.33: 542 - 547.

11. Coppo R, Gianoglio B , Porcellini MG, Maringhini $S$, Frequency of renal diseases and clinical indications for renalbiopsy in children (report of the Italian National Registry ofRenal Biopsies in Children). Group of Renal Immunopathologyof the Italian Society of Pediatric Nephrology and Group of Renal Immunopathology of the Italian Society of Nephrology. NephrolDial Transplant 1998. 13: 293 297.

12. Wong W. Glomerulonephritis-acute. Starship Children's Health Clinical Guideline. 2009; 1-3. 
13. Ranjit RR. Acute post streptococcal glomerulonephritis. Bangladesh J child Health.2014; 38(1):32-39.

14. Blyth CC, Robertson PW, Rosenberg AR. Post streptococcal glomerulonephritis in Sydney: a 16-year retrospective review. J Paediatr Child Health 2007; 43:446.

15. Khalifa EH, Babikir KG, Salma SM, Khalil GAE, El-Hassan AM, et al. (2004) Pattern of Glomerulonephritis in Sudan: Histopathological and Immunofluorescence Study. Saudi J Kidney Dis Transplant 15:176-179.

16. Shah GS,Yadav SP. clinical profile and outcome of acute glomerulonephritis in a tertiary care center in the Nepal, Journal of institute of Medicine; 2014:36(1).29-33.

17. Derakhan A, Hekmat VR. Acute glomerulonephritis in southern Iran. Iran J Pediatr.2008; 18(2):143-148.

18. Rodriguez-Iturbe B. Acute end capillary glomerulo nephritis. In: Davison AM, Cameron JS, Grunfeld J-P, et al, (eds). Oxford textbook of clinical nephrology. Oxford, UK; Oxford University Press.1998; Pp: 613-23.

19. Sulyok E. Acute proliferative glomerulonephritis. In: Avner ED, Harmon WE, Niaudet P, (eds). Pediatric Nephrology. Baltimore; Lippincott Williams \& Wilkins. 2004; Pp: 601-13.

20. Pan CG. Glomerulonephritis in childhood. Curr OpinPediatr. 1997;9(2):154-9.

21. Anochie I, Efe K, Okpere A. Childhood acute glomerulonephritis in Port Harcourt, River State, Nigeria. Niger J Med. 2009; 18(2):162-7.

22. Malla K, Sarma SS, MallaT,ThaplialA.Varied presentation of acute Glomerulo nephritis in Children:singlecentre experience from a developing country. Sultan QaboosUniv Med J. 2008 Jul; 8(2): 193-199.

23. Manhas RS, Patwari A, Raina C, Singh A. Acute ne-phritis in Kashmiri children-a clinical and epidemio-logical profile. Indian Pediatr 1979; 16: 1015-21.

24. G. I. McGill Ugwu. Acute Glomerulonephritis in Children of the Niger Delta Region of Nigeria Saudi J Kidney Dis Transpl 2015; 26(5):1064-1069.

25. Albert H, Rouf $S$. The profile of acute glomerulonephritis among Indonesian children. Paediatrica Indonesia 2005; 45(11):264-269.

26. Roy S, Stapleton FB. Changing perspective in children hospitalized with post streptococcal acute glomerulo-nephritis. PediatrNephrol 1990; 4:585-8.

27. Puri RK, Khanna KK, Raghu MB. Acute glomerulonephritis in children. Indian Pediatric 1976; 3: 707-10.

28. Travis LB, Kalian. Acute nephritic syndrome. In: Postlethwaite, editor. Clinical paediatric nephrology. 2nd ed. ButterWorth-Heinamann Ltd. Linacre House:Jordan Hill; 1994. p. 201-9.

29. Rubin MI. Glomerulonephritis. In: Rubin MI, BarretTM, editors. Pediatric nephrology. Baltimore: Williamsand Wilkins Company; 1975.

30. Lewy JE. Acute post streptococcal glomerulonephritis.PediatrClin North Am 1976; 23:751-8

31. Barrat TM. Glomerular disease and hematuria. In: William DI, Johnson JH, editors. Pediatric urology. 2nd ed. London: Butterworth Company; 1982. p. 87.

32. Brouhard BH, Travis LB. Acute post infectious glomerulonephritis. In: Edelmann CM, editor. Pediatric kid-ney disease. 2nd ed. Boston: Little Brown and com-pany; 1992. p. 1199-215.

33. Kirkpatrick JA, Fleischer DS. The roentgen appear-ance of the chest in acute glomerulonephritis in children. J Pediatr 1964; 64:492-8.

34. Ibadin OM, Abiodun O. Childhood acute glomerulonephritis in Benin City. Nigerian Journal of Pediatrics 2003; 30:45-9. 